\title{
Sciendo
}

\section{ASSOCIATION BETWEEN 4q25 VARIANTS, RISK OF ATRIAL FIBRILLATION AND ECHOCARDIOGRAPHIC PARAMETERS}

\author{
Irina Rudaka ${ }^{1,2, \#}$, Dmitrijs Rots ${ }^{1}$, Arturs Uzars ${ }^{1}$, Oskars Kalējs ${ }^{2}$, and Linda Gailīte ${ }^{1}$ \\ ${ }^{1}$ Scientific Laboratory of Molecular Genetics, Rīga Stradiṇš University, 16 Dzirciema Str., Rīga, LV-1007, LATVIA \\ 2 Pauls Stradiṇš Clinical University Hospital, 13 Pilsoṇu Str., Rīga, LV-1002, LATVIA \\ \# Corresponding author, irina.rudaka@gmail.com
}

Communicated by Aivars Lejnieks

\begin{abstract}
Atrial fibrillation (AF), the most common type of arrhythmia, has a heritable component. Variants at locus $4 q 25$ are best associated with the risk of AF development in genome-wide association studies. Left atrial volume is an independent predictor of recurrence of AF after successful sinus rhythm restoration. The aim of our study was to investigate potential association between genetic variants at $4 q 25$ locus and the risk of $A F$ and echocardiographic parameters. We included $241 \mathrm{AF}$ patients and 119 control individuals into the study. Left ventricle ejection fraction (LVEF, \%) and left atrial volume index $\left(L A V I, \mathrm{ml}^{2} \mathrm{~m}^{2}\right)$ were assessed by transthoracic echocardiography during outpatient visits. We selected five 4q25 genetic variants (rs6825911, rs1126483, rs10004516, rs6838973, rs2200733) for the analysis. Variant rs6838973 was found to be associated with reduced risk of AF in additive (CCTT) and dominant (CC vs. CT+TT) models of inheritance. On the other hand, additive $(C C<C T<T T)$ and dominant (CC vs. CT+TT) models of rs2200733 were associated with greater risk of $A F$. The same variations were found to be associated with age of $A F$ onset. Median LAVI was $39.0 \mathrm{ml} / \mathrm{m}^{2}(I Q R=10.0)$ and median LVEF was $56.0 \%(I Q R=13.0)$. Statistically significant association was observed only between LAVI and variant rs1126483 in the dominant model of inheritance (median LAVI in CC vs. CT+TT - $38 \mathrm{ml} / \mathrm{m}^{2} \mathrm{vs} .40 \mathrm{ml} / \mathrm{m}^{2}, \mathrm{U}=$ 1602.5, $p=0.032$ ). No significant association was found for LVEF and the analysed genotypes.

Key words: arrhythmia, common genetic variants, echocardiography, PITX2, ENPEP.
\end{abstract}

INTRODUCTION

Atrial fibrillation (AF) is the most common arrhythmia, with overall prevalence of $2 \%$, and it has progressively increased worldwide (Chugh Sumeet et al., 2014). It is estimated that in 2030 in Europe there will be 14-17 million AF patients (Zoni-Berisso et al., 2014). Pathogenesis of AF is related to many cardiac and extracardiac risk factors, such as hypertension, coronary heart disease, thyroid dysfunction, excessive alcohol consumption and many others (Kirchhof et al., 2016). Furthermore, specific echocardiographic parameters are associated with increased risk of AF. Among them there are parameters of diastolic dysfunction, dilated left atrium, and left ventricular hypertrophy (O'Neal et al., 2017; Lee and Jang, 2018; Morsy et al., 2018). During the last decade the association of AF and genetic factors has raised interest. The largest AF GWASs to date identified more than 100 related genetic loci. However, the $4 \mathrm{q} 25$ locus was found to be the most significantly associated (Nielsen et al., 2018; Roselli et al., 2018). Therefore, variants in this locus were selected for analysis in the current study. It is known that the risk of AF occurrence increases with each decade of age above 60 years (Schnabel et al., 2015). Previous studies highlighted linkage between genetic factors and time of AF onset (Gudbjartsson et al., 2007; Liu et al., 2017).

The aim of the study was to investigate association of $4 \mathrm{q} 25$ variants with risk of $\mathrm{AF}$, age of onset of $\mathrm{AF}$ and association, and with echocardiographic parameters.

\section{MATERIALS AND METHODS}

The study included 241 patients with persistent and longstanding persistent AF. All patients were admitted to the Latvian Cardiology Centre, Pauls Stradiňš Clinical Univer- 
Table 1. Genetic variants selected for the study

\begin{tabular}{|c|c|c|c|c|}
\hline Genetic variants & Localisation & $\begin{array}{l}\text { Changes of } \\
\text { nucleotides }\end{array}$ & Consequence & Method of genotyping \\
\hline rs6825911 & $\begin{array}{l}\text { ENPEP gene } \\
\text { intronic variant }\end{array}$ & $\mathrm{C}>\mathrm{T}$ & $\begin{array}{l}\text { Intron variant, influence on ENPEP expression in various } \\
\text { tissues (https://gtexportal.org/home/snp/rs6825911) }\end{array}$ & TaqMan assay C_29321008_10 \\
\hline rs 1126483 & ENPEP gene, exon 2 & $\mathrm{~T}>\mathrm{C}$ & Missense & HRM \\
\hline rs 10004516 & ENPEP, exon 1 & $\mathrm{~A}>\mathrm{G}$ & Missense & RFLP - SchI (MlyI) \\
\hline rs6838973 & intergenic & $\mathrm{C}>\mathrm{T}$ & $\begin{array}{l}\text { Change of PITX2 and ENPEP enhancer activity (Aguirre } e t \\
\text { al., 2015; Ye et al., 2016) }\end{array}$ & HRM \\
\hline rs2200733 & intergenic & $\mathrm{C}>\mathrm{T}$ & $\begin{array}{l}\text { Change of PITX2 and ENPEP enhancer activity (Aguirre et } \\
\text { al., 2015; Ye et al., 2016) }\end{array}$ & HRM \\
\hline
\end{tabular}

RFLP, Restriction Fragment Length Polymorphism Analysis (primer sequences available upon request); HRM, High-Resolution Melting Analysis (primer sequences available upon request)

sity Hospital, for direct current cardioversion in order to restore sinus rhythm. All participants signed informed consent before enrolment.

Data on transthoratic echocardiohgraphy examination was available for $137 \mathrm{AF}$ patients. Investigation was performed in an outpatient clinic and was carried out according to a standard protocol accepted by the Latvian Society of Cardiology. For the study two echocardiographic parameters (left atrial volume index (LAVI, $\mathrm{ml} / \mathrm{m}^{2}$ ) and ejection fraction $(\mathrm{EF}, \%)$ ) were used.

The control group included 119 healthy individuals from general practitioner's practice and Internal Disease Department in Madona Hospital. Peripheral blood samples for DNA extraction were obtained from all study participants. DNA was extracted using the commercial kit, innuPREP Blood DNA Mini Kit (Analytik Jena AG, Germany). Five 4 q25 genetic variants were selected for the analysis; their description including the genotyping method is given in Table 1 . Selection of variants was based on minor allele frequency in Europeans (MAF >10\%) from the 1000 Genome Database (http://phase3browser.1000genomes.org) and reports of possible pathogenic implication in AF development (Campione et al., 1999; Kathiriya and Srivastava, 2000). Only variants lacking strong linkage disequilibrium between themselves were selected. The results of genotyping for all variants were confirmed by bidirectional automated sequencing (using BigDye Terminator kit v3.1 according to manufacturer guidelines (ThermoFisherScientific, USA) for 5 to 10 randomly selected samples for each variant with different genotypes; in all cases the genotypes were identical.

Statistical analysis was performed in SPSS v.23.0. Continuous variables were expressed in two ways. Normally distributed variables were expressed as mean value \pm standard deviation (SD). Non-normally distributed variables were expressed as median and interquartile range in parentheses. The Sharipo-Wilk test and histograms were used to assess normality of continuous variables.

For analysis of association between genetic variants and outcome variables several statistical tests were used. For normally distributed data the independent samples t-test and one-way ANOVA were used. For non-normally distributed data the Mann-Whitney $\mathrm{U}$ test and Kruskal-Wallis $\mathrm{H}$ tests were applied. The effect on the outcome of minor allele of each variant was assessed in three models of inheritance additive, dominant, and recessive.

The study was approved by the Latvian Central Medical Ethics Committee (Nr. 1/16-05-09) and was carried out in accordance with the requirements set out in the Declaration of Helsinki.

\section{RESULTS}

Basic characteristics of patients are shown in Table 2. Duration of AF varied between 1 month and 5 years with mean duration 44 months. Mean values of included echocardiografic parameters were within normal ranges.

Among the included genetic variants, two were associated with AF (Table 3). Variant rs6838973 was found to be associated with reduced risk of $\mathrm{AF}$ in additive $(\mathrm{CC}<\mathrm{CT}<\mathrm{TT})$ and dominant (CC vs. CT+TT) models of inheritance. In contrast, additive $(\mathrm{CC}<\mathrm{CT}<\mathrm{TT}$ ) and dominant ( $\mathrm{CC}$ vs. $\mathrm{CT}+\mathrm{TT}$ ) models of rs2200733 were associated with greater risk of AF. The same variants were found to be associated with age of AF onset: variant rs6838973 in additive (median age of onset CC vs. CT vs. TT $=59$ vs. 62 vs. 62.5 years, Chi square $=6.076, p=0.048$ ) and dominant models (CC vs. $\mathrm{CT}+\mathrm{TT}=59$ vs. 62 years, $U=4915.5, p=0.014$ ), and variant rs 2200733 in additive (CC vs. $\mathrm{CT}$ vs. $\mathrm{TT}=62$

Table 2. Basic characteristics of the study group

\begin{tabular}{|l|l|}
\hline Men, $\mathrm{n}(\%)$ & $151(62.7)$ \\
\hline Age, years & $63.94 \pm 10.01$ \\
\hline Duration of AF, months & $43.88(65.1)$ \\
\hline Age of AF onset, years & $65.45(14)$ \\
\hline Lone AF, n (\%) & $21(8.7)$ \\
\hline EDD, mm & $52.85 \pm 6.9$ \\
\hline ESD, $\mathrm{mm}$ & $35(10)$ \\
\hline LAVI, $\mathrm{ml} / \mathrm{m}^{2}$ & $39(10)$ \\
\hline EF, $\%$ & $56(12)$ \\
\hline
\end{tabular}

EDD, end diastolic diameter; ESD, end systolic diameter; LAVI, left atrial volume index; EF, ejection fraction 
Table 3. Association of genetic variants and atrial fibrillation

\begin{tabular}{c|c|c|c|c}
\hline Variation & $\begin{array}{c}\text { Model of } \\
\text { inheritance }\end{array}$ & $\begin{array}{c}\text { Odds ratio } \\
(\mathrm{OR})\end{array}$ & $\begin{array}{c}95 \% \text { Confidence } \\
\text { interval }(\mathrm{CI})\end{array}$ & $p$ value \\
\hline \multirow{2}{*}{ rs6825911 } & Additive & 0.672 & $0.618-1.363$ & 0.672 \\
& Dominant & 0.876 & $0.561-1.367$ & 0.559 \\
& Recessive & 1.246 & $0.317-4.904$ & 0.753 \\
\hline \multirow{2}{*}{ rs1126483 } & Additive & 0.893 & $0.671-1.189$ & 0.440 \\
& Dominant & 0.661 & $0.402-1.086$ & 0.102 \\
& Recessive & 1.088 & $0.674-1.754$ & 0.730 \\
\hline \multirow{2}{*}{ rs10004516 } & Additive & 0.878 & $0.586-1.315$ & 0.528 \\
& Dominant & 0.821 & $0.517-1.305$ & 0.405 \\
& Recessive & 1.246 & $0.317-4.904$ & 0.753 \\
\hline \multirow{2}{*}{ rs6838973 } & Additive & 0.694 & $0.513-0.940$ & $\mathbf{0 . 0 1 8}$ \\
& Dominant & 0.608 & $0.375-0.987$ & $\mathbf{0 . 0 4 4}$ \\
& Recessive & 0.617 & $0.371-1.029$ & 0.064 \\
\hline \multirow{2}{*}{ rs2200733 } & Additive & 1.688 & $1.136-2.510$ & $\mathbf{0 . 0 1 0}$ \\
& Dominant & 1.961 & $1.227-3.133$ & $\mathbf{0 . 0 0 5}$ \\
& Recessive & 1.517 & $0.534-4.311$ & 0.434
\end{tabular}

vs. 61 vs. 52.5 years, Chi square $=7.324, p=0.026$ ) and recessive $(\mathrm{CC}+\mathrm{CT}$ vs. $\mathrm{TT}=62$ vs. 52.5 years, $U=895.5$, $p=0.01)$ models.

Regarding association between variants and echocardiographic parameters, a statistically significant association was observed only between LAVI and variant rs1126483 in the dominant model of inheritance (Figs. 1 and 2) (median LAVI in CC vs. CT+TT $-38 \mathrm{ml} / \mathrm{m}^{2}$ vs. $40 \mathrm{ml} / \mathrm{m}^{2}, U=$ $1602.5, p=0.032$ ). No significant association was found for left ventricle EF and the analysed genotypes (not shown).

\section{DISCUSSION}

Both 4q25 variants showing significant association with AF in our study (rs6838973 and rs2200733) were previously described to be associated with $\mathrm{AF}$ in the literature (Lee et al., 2010; Kiliszek et al., 2011; Ferrán et al., 2014). Our data show that these variants are also associated with age of $\mathrm{AF}$ onset. Data from the first AF related GWAS revealed a correlation between $\mathrm{T}$ allele of rs 2200733 and earlier age of onset in the Icelandic population - AF was diagnosed 2.8 years earlier per each T allele (Gudbjartsson et al., 2007). To the best of our knowledge, no association between rs6838973 and age of AF onset has been previously described.

GWAS identified multiple AF associated variants at $4 \mathrm{q} 25$, which is a non-coding region (Ellinor et al., 2012; Lubitz et al., 2014). The closest protein encoding gene is PITX2, located $150 \mathrm{~kb}$ centromeric to $4 \mathrm{q} 25$ (Gudbjartsson et al., 2007). The next closest gene is ENPEP (Aguirre et al., 2015). It is hypothesised that variants at $4 \mathrm{q} 25$ regulate the function of the proximity genes (Aguirre et al., 2015; Ye et al., 2016). PITX2 has an essential role in cardiac morphogenesis, providing asymmetric cardiac development (Campione et al., 1999; Kathiriya and Srivastava, 2000), and its expression continues in adult heart (Kahr et al., 2011;

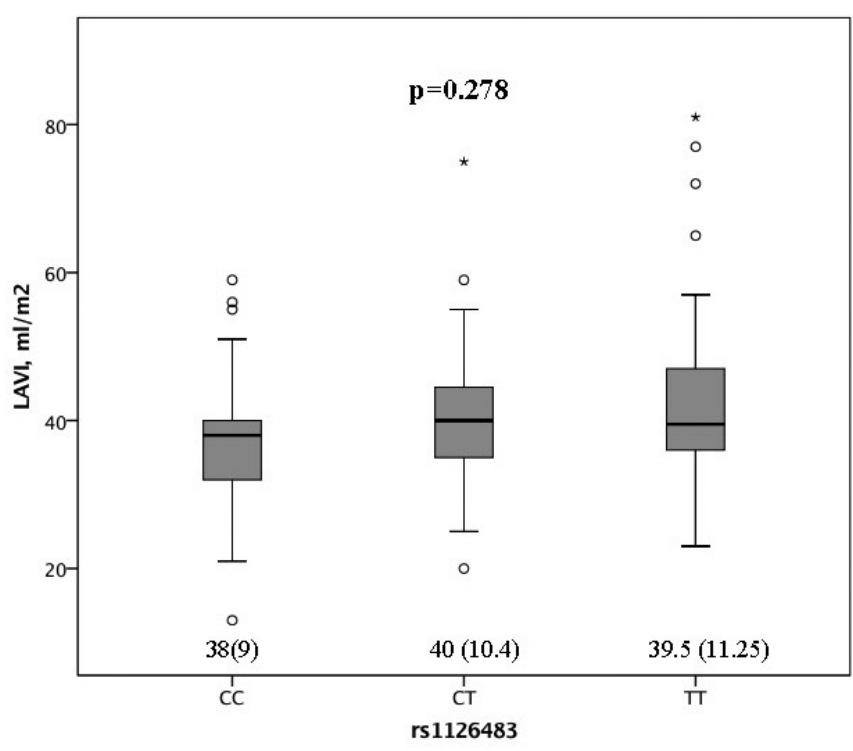

Fig. 1. Association of LAVI and rs1126483 in the additive model of inheritance

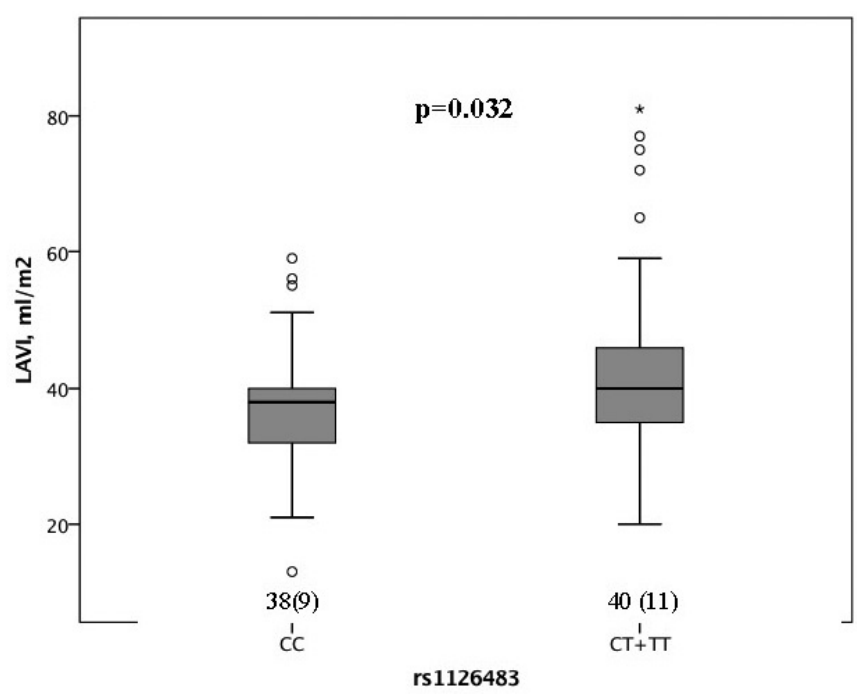

Fig. 2. Association of LAVI and rs1126483 in the dominant model of inheritance

Kirchhof et al., 2011). In an adult mice model it was shown that expression of Pitx2 decreased with ageing (Wang et al., 2010). The postnatal function of Pitx2 is regulation of genes encoding ion transport proteins, intercalated discs and various transcription factors (Tao et al., 2014). However GorePanter et al. (2014) showed that PITX2 expression in adult human left atrial appendage is not associated with the genotype located at $4 \mathrm{q} 25$, and thus the molecular mechanism of linkage between $4 \mathrm{q} 25$ and PITX2 remains unknown. One of the most significant drivers of $\mathrm{AF}$ is the cardiac muscle sleeve around one or more pulmonary veins (Iwasaki et al., 2011). An animal experiment revealed that Pitx2-deficient mice do not develop a pulmonary myocardium sleeve (Mommersteeg et al., 2007). Therefore, we may presume that patients with different AF-related genotypes may have different pulmonary vein morphology. Evidence supporting this hypothesis was provided in a recent study in an AF patients' population, which showed that homozygous carriers 
of T allele at rs2200733 had greater diameter of pulmonary veins (Kiliszek et al., 2011). Indirect support of this is given by the observation that $4 \mathrm{q} 25$ variants, particularly rs2200733, are associated with AF recurrence after successful AF ablation (Husser et al., 2010; Chen et al., 2016; Shoemaker et al., 2013; 2015). Therefore, different morphology of pulmonary veins, mediated by genotype, can lead to earlier AF onset age independently of other risk factors.

Our study showed that the presence of at least one risk allele $(\mathrm{T})$ of variant rs1126483 was associated with greater LAVI in patients with AF. This finding may provide additional explanation and implication of common genetic variants in the pathogenesis of AF.

Left atrial volume is an independent predictor of an incident $\mathrm{AF}$ in the whole population and recurrence after successful catheter ablation (Kathiriya and Srivastava, 2000; Lee et al., 2010; Olsen et al., 2018; Tanabe et al., 2007). Interestingly, South Asians have lower prevalence of AF than Caucasians. O'Neill and colleagues showed that this could be due to morphologic characteristics of the heart and a smaller left atrium in particular (O'Neill et al., 2018).

However left atrial dilation is also a consequence of $\mathrm{AF}$, as persistence of $\mathrm{AF}$ was observed to be associated with both left and right atrial enlargement (Sanfilippo et al., 1990). Predictors of greater left atrial dimensions other than AF are age, body mass index, competitive sport, epicardial adipose tissue, habitual alcohol consumption, and chronic kidney failure (Nistri et al., 2011; Mancio et al., 2018; Plawecki et al., 2018; Voskoboinik et al., 2018).

Increased atrial diameter and volume are correlated with the degree of atrial fibrosis (Knackstedt et al., 2008). Atrial fibrosis plays an important role in pathogenesis of AF. It increases cardiac wavelength and therefore affects re-entry circulation of electrical impulse (Cochet et al., 2018; Saha et al., 2018). Furthermore, atrial fibrosis affects maintenance of $\mathrm{AF}$ and progression of a paroxysmal form to persistent (Morgan et al., 2016).

Genetic predisposition of AF is known for more than a decade and ongoing studies reveal new evidence (Gudbjartsson et al., 2007; Nielsen et al., 2018). Both rare and common genetic variants are associated with AF risk (Feghaly et al., 2018). However, the pathogenic mechanism explaining this association is still under investigation and genome-wide association studies are ongoing. Recently, an association was observed between left atrial dimensions and genetic variations. A risk allele of rs10033464, located near PITX2, was found to be associated with increased left atrial volume (Feghaly et al., 2018). In the present study, association of rs1126483 and LAVI was observed. This variant is located in the ENPEP gene, which encodes enzyme glutamylaminopeptidase A (GAPA). Another genetic variant in the ENPEP gene was previously described in association with risk of AF (Aguirre et al., 2015). GAPA converts angiotensin II into angiotensin III, major components of the renin- angiotensin-aldosterone system (RAAS) (Mizutani et al., 2008). Angiotensin III acts as a central blood pressure regulator by interacting with angiotensin I receptors (AT1). This results in increased blood pressure, salt ingestion and drinking behaviour changes and release of arginine vasopressin (Bodineau et al., 2008). RAAS is well known as a contributor of cardiac fibrosis. This is primarily due to interaction of angiotensin II with AT1, increase in transforming growth factor-beta 1 (TGF-beta 1) and induction of collagen synthesis by cardiac fibroblasts (Lijnen et al., 2000). Although there are no studies showing interaction between angiotensin III and augmentation of fibrosis, the affinity of angiotensin III towards AT1 may also lead to increased production of fibrotic tissue and development of cardiac fibrosis. Thus, a possible linkage of variation in the ENPEP gene and greater LAVI could probably be due to atrial fibrosis.

The study has several limitations. The sample size was small and underpowered; therefore, the findings of the study may be false-positive results. The assessment of left atrial dimension by transthoracic echocardiography may not be efficient enough. More sensitive imaging methods, such as cardiac magnetic resonance imaging, should probably be used.

Our results will need to be confirmed in future studies. As well as a possible mechanism for the association of variant rs1126483 and LAVI should be investigated.

\section{ACKNOWLEDGEMENTS}

The research was carried out with the financial support of Rìga Stradiňš University and Roche Academy Latvia.

\section{REFERENCES}

Aguirre, L. A., Alonso, M. E., Badía-Careaga, C., Rollán, I., Arias, C., Fernández-Miñán, A., López-Jiménez, E., Aránega, A., Gómez-Skarmeta, J. L., Franco, D., Manzanares, M. (2015). Long-range regulatory interactions at the $4 \mathrm{q} 25$ atrial fibrillation risk locus involve PITX2c and ENPEP. BMC Biol., 13, 26

Benjamin Shoemaker, M., Muhammad, R., Parvez, B., White, B.W., Streur, M., Song, Y., Stubblefield, T., Kucera, G., Blair, M., Rytlewski, J., et al. (2013). Common atrial fibrillation risk alleles at 4q25 predict recurrence after catheter-based atrial fibrillation ablation. Heart Rhythm, 10, 394-400.

Bodineau, L., Frugičre, A., Marc, Y., Claperon, C., Llorens-Cortes, C. (2008). Aminopeptidase A inhibitors as centrally acting antihypertensive agents. Heart Failure Rev., 13, 311-319.

Campione, M., Steinbeisser, H., Schweickert, A., Deissler, K., van Bebber, F., Lowe, L. A., Nowotschin, S., Viebahn, C., Haffter, P., Kuehn, M. R., Blum, M. (1999). The homeobox gene Pitx2: Mediator of asymmetric left-right signaling in vertebrate heart and gut looping. Development, 126, 1225-1234.

Chen, F., Yang, Y., Zhang, R., Zhang, S., Dong, Y., Yin, X., Chang, D., Yang, Z., Wang, K., Gao, L., Xia, Y. (2016). Polymorphism rs2200733 at chromosome $4 \mathrm{q} 25$ is associated with atrial fibrillation recurrence after radiofrequency catheter ablation in the Chinese Han population. Amer. J. Transl. Res., 8, 688-697.

Chugh, S. S., Havmoeller, R., Narayanan, K., Singh, D., Rienstr, M, Benjamin, E. J., Gillum, R. F., Kim, Y. H., McAnulty, J. H., Zheng, Z. J., Forouzanfar, M. H., Naghavi, M., Mensah, G. A., Ezzati, M., Murray, C. J. 
(2014). Worldwide epidemiology of atrial fibrillation. Circulation, 129 , $837-847$

Cochet, H., Dubois, R., Yamashita, S., Al Jefairi, N., Berte, B., Sellal, J.-M., Hooks, D., Frontera, A., Amraoui, S., Zemoura, A., et al. (2018). Relationship between fibrosis detected on late gadolinium-enhanced cardiac magnetic resonance and re-entrant activity assessed with electrocardiographici in human persistent atrial fibrillation. JACC Clin. Electrophysiol., 4, $17-29$

Ellinor, P. T., Lunetta, K. L., Albert, C. M., Glazer, N. L., Ritchie, M. D., Smith, A. V., Arking, D. E., Müller-Nurasyid, M., Krijthe, B. P., Lubitz, S. A., et al. (2012). Meta-analysis identifies six new susceptibility loci for atrial fibrillation. Nat. Genet., 44, 670-675.

Feghal, J., Zakka, P., London, B., MacRae, C. A., Refaat, M. M. (2018). Genetics of atrial fibrillation. J. Amer. Heart Assoc., 7, e009884.

Ferrán, A., Alegret, J. M., Subirana, I., Aragončs, G., Lluis-Ganella, C., Romero-Menor, C., Planas, F., Joven, J., Elosua, R. (2014). Association between rs2200733 and rs7193343 genetic variants and atrial fibrillation in a Spanish population, and meta-analysis of previous studies. Rev. Esp. Cardiol. (Engl Ed) 67, 822-829.

Gore-Panter, S. R., Hsu, J., Hanna, P., Gillinov, A. M., Pettersson, G., Newton, D. W., Moravec, C. S., Van Wagoner, D. R., Chung, M. K., Barnard, J., Smith, J. D. (2014). Atrial Fibrillation associated chromosome 4q25 variants are not associated with PITX2c expression in human adult left atrial appendages. PLoS ONE, 9, e86245.

Gudbjartsson, D. F., Arnar, D. O., Helgadottir, A., Gretarsdottir, S., Holm, H., Sigurdsson, A., Jonasdottir, A., Baker, A., Thorleifsson, G., Kristjansson, K., et al. (2007). Variants conferring risk of atrial fibrillation on chromosome 4q25. Nature, 448, 353-357.

Husser, D., Adams, V., Piorkowski, C., Hindricks, G., Bollmann, A. (2010). Chromosome $4 \mathrm{q} 25$ variants and atrial fibrillation recurrence after catheter ablation. J. Amer. Coll. Cardiol., 55, 747-753.

Iwasaki, Y., Nishida, K., Kato, T., Nattel, S. (2011). Atrial fibrillation pathophysiology: Implications for management. Circulation, 124, 2264-2274.

Kahr, P. C., Piccini, I., Fabritz, L., Greber, B., Schöler, H., Scheld, H. H., Hoffmeier, A., Brown, N. A., Kirchhof, P. (2011). Systematic analysis of gene expression differences between left and right atria in different mouse strains and in human atrial tissue. PLOS ONE, 6, e26389.

Kathiriya, I. S., Srivastava, D. (2000). Left-right asymmetry and cardiac looping: implications for cardiac development and congenital heart disease. Amer. J. Med. Genet., 97, 271-279.

Kiliszek, M., Franaszczyk, M., Kozluk, E., Lodzinski, P., Piatkowska, A., Broda, G., Ploski, R., Opolski, G. (2011). Association between variants on chromosome 4q25, 16q22 and 1q21 and atrial fibrillation in the Polish population. PLOS ONE, 6, e21790.

Kirchhof, P., Kahr, P. C., Kaese, S., Piccini, I., Vokshi, I., Scheld, H.-H., Rotering, H., Fortmueller, L., Laakmann, S., Verheule, S., Schotten, U., Fabritz, L., Brown, N. A. (2011). PITX2c is expressed in the adult left atrium, and reducing Pitx $2 c$ expression promotes atrial fibrillation inducibility and complex changes in gene expression. Circ. Cardiovasc. Genet., 4, 123-133.

Kirchhof, P., Benussi, S., Kotecha, D., Ahlsson, A., Atar, D., Casadei, B., Castella, M., Diener, H.-C., Heidbuchel, H., Hendriks, J., et al. (2016). 2016 ESC Guidelines for the management of atrial fibrillation developed in collaboration with EACTS. Eur. J. Cardiothorac. Surg., 50, e1-e88.

Knackstedt, C., Gramley, F., Schimpf, T., Mischke, K., Zarse, M., Plisiene, J., Schmid, M., Lorenzen, J., Frechen, D., Neef, P., Hanrath, P., Kelm, M., Schauerte, P. (2008). Association of echocardiographic atrial size and atrial fibrosis in a sequential model of congestive heart failure and atrial fibrillation. Cardiovascu. Pathol., 17, 318-324

Lee, J., Jang, I. (2018). Predictors affecting postoperative atrial fibrillation in patients after coronary artery bypass graft. Clin. Nurs. Res., doi: $10.1177 / 1054773818809285$
Lee, K.-T., Yeh, H.-Y., Tung, C.-P., Chu, C.-S., Cheng, K.-H., Tsai, W.-C., Lu, Y.-H., Chang, J.-G., Sheu, S.-H., Lai, W.-T. (2010a). Association of RS2200733 but not RS10033464 on 4q25 with atrial fibrillation based on the recessive model in a Taiwanese population. Cardiology, 116, 151-156.

Lee, Y.-S., Hyun, D. W., Jung, B. C., Cho, Y. K., Lee, S. H., Shin, D. G., Park, H. S., Han, S. W., Kim, Y. N. (2010b). Left atrial volume index as a predictor for occurrence of atrial fibrillation after ablation of typical atrial flutter. J. Cardiol., 56, 348-353.

Lijnen, P. J., Petrov, V. V., Fagard, R. H. (2000). Induction of cardiac fibrosis by angiotensin II. Methods Find Exp. Clin. Pharmacol., 22, 709-723.

Liu, L., Ebana, Y., Nitta, J.-I., Takahashi, Y., Miyazaki, S., Tanaka, T., Komura, M., Isobe, M., Furukawa, T. (2017). Genetic variants associated with susceptibility to atrial fibrillation in a Japanese population. Can. J. Cardiol., 33, 443-449.

Lubitz, S. A., Lunetta, K. L., Lin, H., Arking, D. E., Trompet, S., Li, G., Krijthe, B. P., Chasman, D. I., Barnard, J., Kleber, M. E., et al. (2014) Novel genetic markers associate with atrial fibrillation risk in Europeans and Japanese. J. Amer. Coll. Cardiol., 63, 1200-1210.

Mancio, J., Azevedo, D., Fragao-Marques, M., Falcao-Pires, I., LeiteMoreira, A., Lunet, N., Fontes-Carvalho, R., Bettencourt, N. (2018). Meta-analysis of relation of epicardial adipose tissue volume to left atrial dilation and to left ventricular hypertrophy and functions. Amer. J. Cardiol., 123, 523-531.

Mints, Y., Yarmohammadi, H., Khurram, I. M., Hoyt, H., Hansford, R., Zimmerman, S. L., Steinberg, S. J., Judge, D. P., Tomaselli, G. F., Calkins, H., Zipunnikov, V., Nazarian, S. (2015). Association of common variations on chromosome $4 \mathrm{q} 25$ and left atrial volume in patients with atrial fibrillation. Clin. Med. Insights Cardiol., 9, 39-45.

Mizutani, S., Ishii, M., Hattori, A., Nomura, S., Numaguchi, Y., Tsujimoto, M., Kobayshi, H., Murohara, T., Wright, J. W. (2008). New insights into the importance of aminopeptidase A in hypertension. Heart Failure Rev., 13, 273-284

Mommersteeg, M. T. M., Brown, N. A., Prall, O. W. J., de Gier-de Vries, C., Harvey, R. P., Moorman, A. F. M., Christoffels, V. M. (2007). Pitx2c and $N k x 2-5$ are required for the formation and identity of the pulmonary myocardium. Circ. Res. 101, 902-909.

Morgan, R., Colman, M. A., Chubb, H., Seemann, G., Aslanidi, O. V. (2016) Slow conduction in the border zones of patchy fibrosis stabilizes the drivers for atrial fibrillation: Insights from multi-scale human atrial modeling. Front Physiol., 7, 474

Morsy, M., Slomka, T., Shukla, A., Uppal, D., Bomb, R., Akinseye, O. A., Koshy, S. K. G., Garg, N. (2018). Clinical and echocardiographic predictors of new-onset atrial fibrillation in patients admitted with blunt trauma. Echocardiography, 35, 1519-1524.

Nielsen, J. B., Thorolfsdottir, R. B., Fritsche, L. G., Zhou, W., Skov, M. W., Graham, S. E., Herron, T. J., McCarthy, S., Schmidt, E. M., Sveinbjornsson, G., et al. (2018). Biobank-driven genomic discovery yields new insight into atrial fibrillation biology. Nat. Genet., 50 1234-1239.

Nistri, S., Galderisi, M., Ballo, P., Olivotto, I., D’Andrea, A., Pagliani, L., Santoro, A., Papesso, B., Innelli, P., Cecchi, F., Mondillo, S. (2011). Determinants of echocardiographic left atrial volume: Implications for normalcy. Eur. J. Echocardiogr., 12, 826-833.

Olsen, F. J., Møgelvang, R., Jensen, G. B., Jensen, J. S., Biering-Sørensen, T. (2018). Relationship between left atrial functional measures and incident atrial fibrillation in the general population. JACC: Cardiovasc. Imaging, 18, 14-17.

O’Neal, W. T., Sandesara, P., Patel, N., Venkatesh, S., Samman-Tahhan, A., Hammadah, M., Kelli, H. M., Soliman, E. Z. (2017). Echocardiographic predictors of atrial fibrillation in patients with heart failure with preserved ejection fraction. Eur. Heart J. Cardiovasc. Imaging, 18, 725-729.

O’Neill, J., Swoboda, P. P., Plein, S., Tayebjee, M. H. (2018). Left atrial size and function in a South Asian population and their potential influence on the risk of atrial fibrillation. Clin. Cardiol., 41, 1379-1385. 
Plawecki, M., Morena, M., Kuster, N., Chenine, L., Leray-Moragues, H., Jover, B., Fesler, P., Lotierzo, M., Dupuy, A.-M., Klouche, K., Cristol, J. P. (2018). sST2 as a new biomarker of chronic kidney disease-induced cardiac remodeling: Impact on risk prediction. Mediators Inflamm., 2018, 3952526.

Roselli, C., Chaffin, M. D., Weng, L.-C., Aeschbacher, S., Ahlberg, G., Albert, C. M., Almgren, P., Alonso, A., Anderson, C. D., Aragam, K. G., et al. (2018). Multi-ethnic genome-wide association study for atrial fibrillation. Nat. Genet., 50, 1225-1233.

Saha, M., Roney, C. H., Bayer, J. D., Meo, M., Cochet, H., Dubois, R., Vigmond, E. J. (2018). Wavelength and fibrosis affect phase singularity locations during atrial fibrillation. Front Physiol, 9, 1207.

Sanfilippo, A. J., Abascal, V. M., Sheehan, M., Oertel, L. B., Harrigan, P., Hughes, R. A., Weyman, A. E. (1990). Atrial enlargement as a consequence of atrial fibrillation. A prospective echocardiographic study. Circulation, 82, 792-797.

Schnabel, R. B., Yin, X., Gona, P., Larson, M. G., Beiser, A. S., McManus, D. D., Newton-Cheh, C., Lubitz, S. A., Magnani, J. W., Ellinor, P. T., Seshadri, S., Wolf, P. A., Vasan, R. S., Benjamin, E. J., Levy, D. (2015). 50 year trends in atrial fibrillation prevalence, incidence, risk factors, and mortality in the Framingham Heart Study: A cohort study. Lancet, 386, 154-162.

Shin, S.-H., Park, M.-Y., Oh, W.-J., Hong, S.-J., Pak, H.-N., Song, W.-H., Lim, D.-S., Kim, Y.-H., Shim, W.-J. (2008). Left atrial volume is a predictor of atrial fibrillation recurrence after catheter ablation. J. Amer. Soc. Echocardiogr., 21, 697-702.

Shoemaker, M. B., Bollmann, A., Lubitz, S. A., Ueberham, L., Saini, H., Montgomery, J., Edwards, T., Yoneda, Z., Sinner, M. F., Arya, A., et al.
(2015). Common genetic variants and response to atrial fibrillation ablation. Circ. Arrhythm. Electrophysiol., 8, 296-302.

Tanabe, K., Yamaguchi, K., Tani, T., Yagi, T., Katayama, M., Tamita, K., Kinoshita, M., Kaji, S., Yamamuro, A., Morioka, Sokada, Y., Kihara, Y. (2007). Left atrial volume: Predictor of atrial fibrillation in patients with degenerative mitral regurgitation. J. Heart Valve Dis., 16, 8-12.

Tao, Y., Zhang, M., Li, L., Bai, Y., Zhou, Y., Moon, A. M., Kaminski, H. J., Martin, J. F. (2014). Pitx2, an atrial fibrillation predisposition gene, directly regulates ion transport and intercalated disc genes. Circ. Cardiovasc. Genet., 7, 23-32.

Voskoboinik, A., Costello, B. T., Kalman, E., Prabhu, S., Sugumar, H., Wong, G., Nalliah, C., Ling, L.-H., McLellan, A., Hettige, T., Springer, F., La Gerche, A., Kalman, J. M., Taylor, A. J., Kistler, P. M. (2018). Regular alcohol consumption is associated with impaired atrial mechanical function in the atrial fibrillation population: A cross-sectional MRI-based study. JACC Clin. Electrophysiol., 4, 1451-1459.

Wang, J., Klysik, E., Sood, S., Johnson, R. L., Wehrens, X. H. T., Martin, J. F. (2010). Pitx2 prevents susceptibility to atrial arrhythmias by inhibiting left-sided pacemaker specification. Proc. Natl. Acad. Sci. U.S.A., 107, 9753-9758.

Ye, J., Tucker, N. R., Weng, L.-C., Clauss, S., Lubitz, S. A., Ellinor, P. T. (2016). A functional variant associated with atrial fibrillation regulates PITX2c expression through TFAP2a. Amer. J. Hum. Genet., 99, $1281-1291$.

Zoni-Berisso, M., Lercari, F., Carazza, T., Domenicucci, S. (2014). Epidemiology of atrial fibrillation: European perspective. Clin. Epidemiol., 6, 213-220.

Received 11 January 2019

Accepted in the final form 16 October 2019

\section{ASOCIĀCIJA STARP 4Q25 VARIANTIEM, ĀTRIJU FIBRILĀCIJAS RISKU UN EHOKARDIOGRĀFISKIEM PARAMETRIEM}

Ātriju fibrilācija (ĀF) ir visbiežāk sastopamais aritmiju veids. ĀF ir zināma ǵenētiska predispozīcija. Ģenētiskiem variantiem, kas lokalizēti 4q25 lokusā, ir visciešākā saistība ar ĀF attīstības risku. Šì saistība tika aprakstīta vairākos genoma-plašos asociācijas pētījumos. Kreisā priekškambara tilpums ir neatkarīgs prognostiskais faktors $\bar{A} F$ recidīvu attīstībai pēc sinusa ritma atjaunošanas. Pētījuma mērkis bija noskaidrot asociāciju starp 4q25 genētiskām variācijām, ĀF risku un ehokardiogrāfiskiem parametriem. Pētījumā tika iekḷauts 241 ĀF pacients un 119 kontroles indivīdi. Kreisā kambara izsviedes frakcija (LVEF, \%) un kreisā priekškambara tilpuma indekss tika noteikti, veicot transtorakālo ehokardiogrāfiju ambulatori. Saistības analīzei tika izvēlētas piecas 4q25 variācijas (rs6825911, rs1126483, rs10004516, rs6838973, rs2200733). Variants rs6838973 ir asociēts ar zemāku ĀF risku additīvajā (CC<CT<TT) un dominantajā (CC pret CT+TT genotipiem) iedzimšanas modelī. Tāpat arī rs2200733 additīvais un dominantais modelis arī ir statistiski nozīmīgi saistīti ar lielāku $\bar{A} F$ risku. LAVI mediāna ir 39,0 ml/m² (IQR = 10,0), bet LVEF - 56,0\% (IQR = 13,0). Šis variācijas ir saistītas arī ar vecumu, kurā pirmreizēji manifestējas ĀF. LAVI mediāna $39,0 \mathrm{ml} / \mathrm{m}^{2}$ (IQR = 10,0) un EF mediāna 56,0\% (IQR = 13,0). Statistiski nozīmīga saistība ir starp LAVI un variācijas rs 1126483 dominanto iedzimšanas modeli (LAVI mediāna CCpret CT+TT - attiecīgi $38 \mathrm{ml} / \mathrm{m}^{2} \mathrm{un} 40 \mathrm{ml} / \mathrm{m}^{2}, U=$ $1602,5, p=0,032)$. Asociāciju starp LVEF un analizētiem genotipiem nenovēro. 